\title{
Carbon-Silica Composites from Sago Waste for the Removal of Chromium, Lead, and Copper from Aqueous Solution: Kinetic and Equilibrium Isotherm Studies
}

\author{
Zainab Ngaini (D) Yogasunthari Rajan • \\ Rafeah Wahi
}

Received: 27 February 2021 / Accepted: 8 October 2021

(C) The Author(s), under exclusive licence to Springer Nature Switzerland AG 2021

\begin{abstract}
Utilizing agricultural wastes into valueadded products of a low-cost adsorbent has become of interest in recent years. In this study, sago-silica composite with a ratio of 80:20 (w/w\%) was prepared via chemical grafting of abundantly available sago waste and rice husk. The physicochemical properties of the composites were characterized, and their efficiencies as adsorbents on the removal of chromium $(\mathrm{Cr})$, lead $(\mathrm{Pb})$, and copper $(\mathrm{Cu})$ in aqueous media were studied as a function of $\mathrm{pH}$, adsorbent dosage, initial concentration, and contact time. Results showed that the sago-silica composite has a more extensive surface area of $227.7 \mathrm{~m}^{2} / \mathrm{g}$ compared to SAC (167.3 $\mathrm{m}^{2} / \mathrm{g}$ ). The adsorption of $\mathrm{Cr}$ and $\mathrm{Cu}$ gave excellent monolayer and heterolayer adsorption on sago-silica composite represented by Langmuir and Freundlich's isotherm based on coefficient regression, $R^{2}>0.9$. Pseudo-second-order kinetics model showed best fitted with excellent adsorption capacity $q_{\mathrm{e}}$ of $\mathrm{Cr}, \mathrm{Pb}$, and $\mathrm{Cu}$ adsorption on sago-silica composites, which
\end{abstract}

Supplementary Information The online version contains supplementary material available at https://doi. org/10.1007/s11270-021-05393-9.

Z. Ngaini $(\bowtie) \cdot$ Y. Rajan $\cdot$ R. Wahi $(\bowtie)$

Faculty of Resource Science and Technology, Universiti

Malaysia Sarawak, 94300 Kota Samarahan, Sarawak,

Malaysia

e-mail: nzainab@unimas.my

R. Wahi

e-mail:wrafeah@unimas.my demonstrated the occurrence of chemisorption process between the composite and metal ions. The composite from carbon-silica is one of the cost-effective natural sorbents which demonstrate excellent removal of heavy metal from the aqueous environment.

Keywords Sago hampas $\cdot$ Rice husk $\cdot$ Activated carbon $\cdot$ Silica grafting $\cdot$ Heavy metals $\cdot$ Adsorption

\section{Introduction}

Most heavy metal pollution results from industries such as electroplating, mining, metallurgy, paint, and ceramic (Özsin et al., 2019). Heavy metal has become a major concern due to its non-biodegradable, toxic, carcinogenic, and teratogenic nature (Zhao et al., 2016). Heavy metal can accumulate in living tissues through the food chain and bring harmful effects on humans, animals, and the ecosystem (Malik et al., 2016). Despite the rapid development in heavy metal removal technologies, the practicality depends on its cost, effectiveness, and type and complexity of wastewater treated.

Heavy metal removal from wastewater using activated carbon (AC) has been widely applied due to its excellent properties. The high porosity, high surface area, high carbon content (up to $90 \%$ carbon), and the presence of various important functional groups in AC favor heavy metal adsorption (Heidarinejad et al., 2020). There are many sources 